\title{
Books of Exceptional Age
}

$A^{\mathrm{N}}$

alert college purchasing officer once asked a college librarian why he paid premium prices for out-of-print books. The purchasing-officer's logic was simple. An out-of-print book got that way because there was not enough demand to enable the publisher to continue manufacturing and selling the book. If there was lack of demand, why did the local college library want a book which others did not want?

Librarians and booksellers have many answers to this seemingly simple logic. We all know how desperately a few copies of an out-of-print book may be needed. The first printing filled most of the demand, and there is not demand enough to justify a second printing. But the simple supply and demand logic is still tantalizing.

The writer has made certain quantitative studies of book obsolescence in an attempt to show how rapidly books go out of date. ${ }^{1}$ Here he presents a few case studies in an effort to determine what is the nature of books of exceptional longevity.

The difference between the methods (and sometimes the results) of detailed case studies and broad statistical analyses are too well-known to need recounting. The emphasis in the previous studies has been on statistical analysis of the ages or imprint dates of titles included in the three select lists of books compiled by Shaw and Mohrhardt. $^{2}$ These compilers set out to list good

\footnotetext{
1 "Obsolescence of Books in College Libraries." Col. lege and Research Libraries 5:115-25, March 1944.

"Obsolete Library Books." Scientific Monthly

64:421-27, May 1947. A List of Books for College Libraries. A.L.A., Chicago, I931.

- - Supplement 193I-I938. A.L.A., Chicago,

1940. College Libraries. A.L.A., Chicago, 1937.
}

books for college and junior college libraries. Analysis of the distribution of imprint dates showed a marked preference for new titles and recent editions.

The Shaw list, however, contains twelve titles (Table I) which were over a hundred years of age at the time the list was issued. All were out-of-print and obtainable only in the secondhand market; hence, they may be regarded as relatively difficult to secure for a library which did not have them and certainly limited in supply. The writer will make no attempt to solve the problem of how such a limited supply might be spread among so many institutions seeking to meet the specifications of the list. $\mathrm{He}$ can only offer suggestions and speculations as to why the titles were included at all. To a third question, as to why, if these titles are so important and needed by so many libraries, they have not been revised and published in new editions, there seems to be no final answer.

By design, all titles in the Mohrhardt list were in print at the time of compilation. The oldest, which was eighty-six years old at the time of compilation in 1936 , was Madame de Staël's De l'Allemagne, I850 ("French," p. I15). Next in age was Smith's English-Latin Dictionary, I 87 I ("Classics," p. I I). Third was Mill's Three Essays on Religion, I874 ("Philosophy," p. 236). All other titles were less than sixty years old, with imprint dates of 1877 or later. Five subjects had no titles more than thirty years old, viz., "Chemistry," "Health and Physical Education," "Mathematics," "Physics," and "Psychology." 


\section{TABle I}

Titles in the Shaw List 100 Years or More Old

$\begin{array}{lrllr}\text { Subject } & \text { Page } & \text { Author } & \text { Title } & \text { Date } \\ \text { English } & \text { I46 } & \text { Fuller } & \text { History of the Worthies } & \text { I8I I } \\ & \text { I56 } & \text { Johnson } & \text { Rambler } & \text { I825 } \\ & \text { I88 } & \text { Bartram } & \text { Observations } & \text { I75I } \\ & \text { I90 } & \text { Barlow } & \text { Columbiad } & \text { I813 } \\ & \text { I90 } & \text { Dennie } & \text { Lay Preacher } & \text { I796 } \\ \text { General } & 204 & \text { Sedgwick } & \text { Redwood } & \text { I824 } \\ \text { History } & 311 & \text { Camoes } & \text { Lusiad, tr. by Musgrave } & \text { I826 } \\ & 402 & \text { Roper } & \text { Life of More } & \text { I822 } \\ \text { Philosophy } & 455 & \text { Long } & \text { History of Jamaica } & \text { I774 } \\ \text { Romance Languages } & 504 & \text { Hutcheson } & \text { Moral Philosophy } & \text { I755 } \\ & 621 & \text { Fontenelle } & \text { Entretiens } & \text { I82I } \\ & 624 & \text { LeSage } & \text { Oeuvres } & \text { I8IO }\end{array}$

None of the great classics such as the Bible, Homer, or Shakespeare is included among these older titles. It is not because the classics are not included but because they are included in later editions. Because they are classics, there is a steady flow of textual revision and commentary, and the preference is for the latest. Then, too, every age demands reinterpretations of classics in its own terms.

\section{Case Studies}

These fifteen older titles seem to represent, then, not the ultimate in eternal values, but the twilight period of obsolescence. They will be examined in detail as follows.

First, the full title as specified in the lists will be cited. Then there will be a brief bibliographical note on editions. The holdings of the title by the five libraries surveyed will be indicated. In a brief comment, the investigator will try to point out the generally accepted opinion as to the importance of the work and will discuss the significance and relationship of the imprint date to the study as a whole.

\section{Case I}

Barlow, Joel. The Columbiad. A poem. With the last corrections of the author. Paris, Printed for F. Schoell, I8I3. xl,
488 p., 2 pl. (incl. front.), 2 port. Out-ofprint. (8-387I)

Note: First published i 807 in luxurious format, sponsored by Robert Fulton. Although this 1813 edition is the latest listed by Sabin and the Cambridge History of American Literature, there was a lesser-known edition published in Washington, D.C., in I 825. Parts have been reprinted in various anthologies.

Holdings: None.

Comment: Barlow (I754-1812) was poet, patriot, diplomat, and businessman. This heroic epic, in elegant, grandiose, and sometimes turgid phrasing, is typical of the rising spirit of nationalism at the time. It is now of interest as an outstanding contemporary document rather than as a lasting piece of literature. History is not complete without it, yet no scholar has yet seen fit to bring out a critical edition.

\section{Case 2}

Bartram, John. Observations on the Inhabitants, Climate, Soil, Rivers, Productions, Animals, and Other Matters Worthy of Notice. Made by Mr. John Bartram, in his travels from Pensilvania to Onondago, Oswego and the Lake Ontario in Canada. To which is annex'd a curious account of the cataracts at Niagara. By Mr. Peter Kalm. ... London, Printed for J. Whiston and B. White, I75I. viii, 94p., front. (fold. plan). Out-of-print. (I-I6152)

Note: A reprint, in an edition of 300 copies, was issued at Geneva, N.Y., in I895.

Holdings: $\mathrm{B}$

Comment: Bartram ( I 70I-77) was a noted 
early American traveler and scientist, with an aptitude for clear and homely narrative. The title is an important item of early Americana but hardly a classic. In view of the reprint (I895), it is difficult to regard the earlier date (I75I) as of great significance. In his sketch in the Dictionary of American Biography, D. C. Peattie records his regret that Bartram's letters and biography have been neglected.

\section{Case 3}

Camoes, Luiz De. The Lusiad, an Epic Poem. Tr. from the Portuguese by Thomas Moore Musgrave. London, Murray, 1826. xxi, 585p. Out-of-print. (I-10094)

Note: There are at least seven other translations, several more recent. The latest to be published is that of Fanshaw (1608-66) edited by J. D. M. Ford (Harvard, 1940).

Holdings: Library $\mathrm{B}$ has two other translations.

Comment: The Lusiad is pre-eminent in Portuguese literature. The reason for the Shaw list preference for Musgrave's translation is not made clear. But if this translation is required, the volume of this date $(1826)$ is the only one available. The format is handsome and there are copious notes.

\section{Case 4}

Dennie, Joseph. The Lay Preacher; or Short Sermons, for Idle Readers. Walpole, Newhampshire, Printed by D. Carlisle, jun., I796. iv, I32p. Out-of-print. (7-3710)

Note: A second selection was issued in I 8 I 7 by John E. Hall. Dennie's Letters were issued in 1936 (Maine University Press). Subsequent to the time this study was originally made (1942-43), a reprint combining the 1796 and 1817 editions was edited by Milton Ellis and published by Scholars' Facsimiles and Reprints in 1943.

Holdings: None.

Comment: Dennie (I768-1812) enjoyed great popularity during his lifetime and was sometimes called "The American Addison." But he was soon eclipsed by Washington Irving. "His failure to get his books published, and the neglect of his early biographers have doomed him to an unmerited obscurity," according to G. W. Fuller in the Dictionary of
American Biography. Continued interest seems to be based on his intrinsic merit and his commanding position in early American letters. This interest has resulted in the reprint noted and may someday result in a comprehensive and critical collection of his essays and other works. When such a volume or volumes are published, the title listed and the reprint will immediately become quite obsolete.

\section{Case 5}

Fontenelle, Bernard Le Bovier De. Entretiens sur la pluralite des mondes, augmentés des Dialogues des morts. . . . Nouv. ed., Paris, Bossange, I82I. xvi, 4rop., fold. front. Out-of-print. (5-I4I63)

Note: The Bibliothèque Nationale Catalogue lists 34 editions of the Entretiens up to I9II. Many of them lack the Dialogues, however. There are 12 separate editions of the Dialogues listed. There have been several English translations. The Entretiens were not listed as in print in La Librairie Française in 1931. The Library of Congress depository catalog shows the 182 I edition only. Holdings: None.

Comment: Fontenelle (1657-1757) was important as an "occasional" writer early in the eighteenth century, and the title in hand is an early scientific work illustrative of the time. It is difficult to attribute special importance to the edition of 1821 . The Dialogues, which are not available in some of the other editions listed by the Bibliothèque Nationale, are included by Shaw as a separate title on the same page.

Selection of this date may be an accidental one, due to the availability of the Library of Congress card.

\section{Case 6}

Fuller, Thomas. The History of the Worthies of England. . . A new ed., with a few explanatory notes, by John Nichols. London, Printed for Rivington, I8II. 2V., front. (port.) Out-of-print. (23-5747)

Note: The first edition was issued in 1662 , the second in $18 \mathrm{II}$, and the last in 1840 (London; Tegg, 3 vols). Modern Selections are available (Oxford, 1928). The Library of Congress depository catalog includes cards for the I8I I and I840 editions.

Holdings: A. 
Comment: Fuller (I608-6I) was a royalist and an anglican divine. The Worthies is a gazetteer of England, with many short biographical sketches and lists of officials. The edition of $I 8 I I$ is in two large quarto volumes, well-printed. The edition of 1840 is in three volumes of more convenient size but inferior paper. Both have indices and footnotes.

The interest and importance of the Worthies today are aptly characterized, and an interesting sidelight on obsolescence in general is given in the following words from an introduction to the Selections by E. K. Broadus (Oxford, I928, p.vii) :

Fuller's folios have long since been broken up into numerous volumes; but, even in this more usable form, they still make what Lamb called "massy reading," and to the pleasure-seeker their titles are as forbidding as their bulk. What reader would turn for delectation to six volumes of a Church History or three stout volumes (the Worthies) filled with half-page biographies of persons whose candle flickered out more than three centuries ago? Or who would seek lively reading in a collection of "Characters," illustrating "The Good Wife," "The Good Husband," "The Good Widow," "The Good Landlord," and more, under the heading of The Holy State? Surely these must be (the words are Fuller's) mere "Auxiliary books, only to be repaired to on occasions," or even "such as are mere pieces of formality, so that if you look on them you look through them; and he that peeps through the casement of the index, sees as much as if he were in the house."

\section{Case 7}

Hutcheson, Francis. A System of Moral Philosophy; in Three Books; Pub. from the Original Mss. by his Son Francis Hutcheson. To Which Is Prefixed Some Account of the Life, Writings, and Character of the Author by the Rev. William Leechman. London, Sold by A. Miller, I775*. 2v. Out-of-print. (10-32132)

Note: Published posthumously and never reprinted.

Holdings: None.

Comment: Hutcheson (I694-1746) holds a prominent place in the history of Scottish philosophy. $\mathrm{He}$ is not of great interest at present compared, for example, with Bishop Butler (I692-I752) whose words are available in modern editions.

\footnotetext{
* Typographical error in Shaw list for 1755 .
}

Case 8

Johnson, Samuel. The Rambler; a Periodical Paper, Published in 1750, 1751, 1752. London, Jones, I825. vii, 35Ip., front. (port.) (British essayists). Out-of-print. (5-I6682)

Note: The Rambler has been reprinted more than twenty times. The latest edition in the British Museum Catalogue is 1876 (2 vols. with a sketch of the author's life by Sir Walter Scott. Selections are available and one is specified by Mohrhardt (ed. by W. H. White, Oxford, 1907).

Holdings: $\mathrm{B}, \mathrm{C}$, have complete editions other than 1825 .

Comment: The importance of Johnson (1709-84) and his Rambler is unquestioned. So many editions, in such quantities, have been issued that sets are easy to obtain, although technically the title is out-of-print.

Choice of an edition may rest on format, including legibility, and on availability. The date of 1825 is without particular significance but is indicative of the period from which a set must be chosen.

\section{Case 9}

LeSage, Alain René. Oeuvres. . . . Paris, Leblanc, I810. I6v., fig. $\$ 32$. (6 d.)

Note: There are other collections as follows: I 783, I 5 vols; I 821 , I 2 vols; I 823, I 6 vols (or 32 vols); 1828 , I 2 vols. Complete details are given by H. Cordier, Essai Bibliographique, Paris, 1910, and in the Catalogue Generale of the Bibliothèque Nationale. There is no recent or definitive edition such as in the series, Les Grands Ecrivains. Many individual titles are available in various editions.

Holdings: A has Oeuvres, 1783.

Comment: The importance of LeSage ( $1668-1747)$ in early eighteenth century French literature is unquestioned. A library which wishes a set of his works must get one at least a century old. That a more recent and definitive edition of his works has not been published is due doubtless to a combination of factors including (a) the bulk of his writings; (b) the frequent issue of his more popular titles as contrasted with the lack of interest in others; and (c) his failure to achieve first rank in French letters.

This entry in the Shaw list is unusual in that it is not reproduced from a Library of 
Congress card and no card number is cited. The Library of Congress depository catalog contains cards for the edition of 1821 (Paris, Renouard) and a reprint of 1828 (Paris, Ledoux ).

\section{Case 10}

Long, Edward. The History of Jamaica; or, General Survey of the Antient and Modern State of That Island: with Reflections on its Situation, Settlements, Inhabitants, Climate, Products, Commerce, Laws, and Government. Illustrated with copper plates. London, Lowndes, I774. 3v. fold. fronts. (v.I-2). plates ( 1 fold.) fold. maps, plan. Out-of-print. (2-11573)

Note: Never reissued, although the author prepared revision. No other full history of Jamaica has since been published.

\section{Holdings: None.}

Comment: Long (1734-1813) was highly praised for the work at the time but later condemned it and prepared a revision. Several brief histories have since appeared, but the island is less the center of interest it once was. Shaw also lists $A$ History of Jamaica ...to the Year 1872 by W. J. Gardner, new ed., New York, Appleton, 1909, 5iop.

For a full account of the history of Jamaica, Long's work is undoubtedly necessary. But, although Sabin in his Dictionary of Books Relating to America describes it as not "excessively rare," it is certainly not generally available. There is need for a comprehensive modern work which in part might be based on Long as a primary source.

\section{Case II}

Mill, John Stuart. Three Essays on Religion. Ed. by Helen Taylor. Longmans, 1874 . xi, 302p. \$1.80. E16-62.

Note: Posthumously published and still in print. The original issue was dated 1874 . Various impressions have been made since that date. Columbia University has a copy dated 1885, with the designation "Third edition." A copy was purchased from Longmans Green in New York by Queens College in 1938. The binder's title on the spine as well as the half-title is Three Essays on Religion. The title page reads Nature, the Utility of Religion and Theism. . . . New impression reprinted from the third edition. London, Longmans, 1923. The plates with which it is printed are obviously quite worn and appear to be the same as those from which earlier impressions have been taken. Early American impressions published by Holt appear to be from the same plates but have a fourth part, viz., "Berkeley's Life and Writings."

Holdings: A (1923); B (1884, with "Berkeley's Life and Writings," p.261-302).

Comment: There has been no great occasion for revision of this work, and the steady sale has justified occasional new impressions. It is not unusual for a publisher to disguise a new impression from old plates with a new date and sometimes a new title. As Mohrhardt specifically indicates that all his titles are in print, the 1923 issue described obviously meets his intent, although it does not have the fourth essay. The date of 1874 comes from the Library of Congress card. Somewhere in the process of checking with the publishers as to whether the book was still in print, there was failure to record the new title and date.

The date of 1874 appears to be without significance for this study. It might just as well have been 1923 .

\section{Case 12}

Roper, William. The Life of Sir Thomas More, by his Son-in-law, with Notes, and an Appendix of Letters. A new ed., rev. and cor., by S. W. Singer. Chiswick, From the press of C. Whittingham, for R. Triphook, London, I822. I95p., front. (port.) Now published by Blackie (Library of Golden Prose), 1/3. (5-969)

Note: As the Shaw entry indicates, the 1822 edition is not required. The Life is short and has frequently been reprinted, sometimes as part of the introduction to the Utopia. It is also included in some editions (among them Everyman's) of Anne Manning's adaptation, The Household of Sir Thomas More. It has also been published under the title, The Mirrour of Vertue in Worldly Greatness. The Early English Text Society issued a copiously annotated and carefully collated text in 1935 .

Holdings: A, in Everyman, no date, and 1935. B, in Sampson's edition of the Utopia, 1910. E, in Selections, 1924.

Comment: The Life by Roper (1496-1578) was first circulated in manuscript form, and consequently there are the usual problems 
of textual variations. The Guide to Historical Literature (New York, 193I) lists only the first edition of 1626 (Item L47 I) and new editions of 1903 and 1924. The Cambridge Bibliography of English Literature lists the editions by Rhys in I890 and Gollancz in 1902 and 1903, reprinted 1910. The 1935 edition should settle most textual problems and of course supersede the 1822 edition by Singer.

The date of 1822 cannot be regarded as of great significance, although it represents the first issue of one of the better texts. It is not recommended by the leading guides in history and English literature. With the coming of the 1935 edition, the 1822 edition may be considered quite obsolete for the college library.

The designation of the date 1822 may have been an accidental one, incident to the selection of the Library of Congress card, or the other editions as parts of other works, may have been overlooked.

\section{Case 13}

Sedgwick, Catharine Maria. Redwood; $a$ Tale. Bliss \& White, 1824. 2v. Out-ofprint. (8-I I246)

Note: Later reprints, with some new material and author's revisions, appeared in 1850 and 1856 .

Holdings: None of this title, but some of other titles by the same author.

Comment: A conventional romantic moralistic novel of the day. Sedgwick ( $1789-1867$ ) was once the most popular authoress in the United States. This title is typical of her work and times.

Whether the editions of 1850 and 1856 are superior to that of 1824 is of relatively slight consequence. No modern editions are available and there is little interest in her work today.

\section{Case 14}

Smith, Sir William. A Copious and Critical English-Latin Dictionary. By William Smith and Theophilus D. Hall. To which is added a dictionary of proper names. American Book Co., I871. xi, 964p., Il., 709-54p. \$6. [I-4278]

Note: The problem of this date is similar to that of Mill's Three Essays (Case II). The preface to the dictionary was signed in I 870 and the book published and copyrighted in 1871 . So far as is known, there have been few if any changes in the plates since that time. Various impressions have carried later dates, but recent copies sold by the publishers have carried no date except 1870 in the preface and $187 \mathrm{I}$ in the copyright claim.

Holdings: A, B, E.

Comment: Smith (1813-93) was the prodigious compiler of a number of encyclopedias and dictionaries on classical subjects. They are standard reference works which have never been superseded. The imprint date of $187 \mathrm{I}$ is of doubtful significance for this study. It does indicate the first issue. It does not mark any important distinction in usefulness from a volume with a later date. Specification of this date conflicts with the general Mohrhardt specification that all books listed be in print. The book which is in print and now on sale does not carry this date.

That the publishers have seen fit to keep this title on the market for over seventy years does have implications for the study of obsolescence. This work has no close competitors. Its subject is one of declining interest, but the volume is indispensable on occasions. An extensive revision, to incorporate new words in English, if not in Latin, is possible but not likely to be successful commercially. That this title has lived so long unchanged is due in part to its intrinsic merit and in part to diminished interest in the field. The lack of interest is insufficient support for competition and revision.

\section{Case 15}

Staël-Holstein, Anne Louise Germaine (Necker) De. De l'Allemagne. Paris, Firmin-Didot, I850. 592p., front. (port.) I 2 Fr. [36-I364]

Note: First published in 1810 . There are many other editions of this title. Several of them, including one published by FirminDidot, are listed as in print in La Librairie Francaise, 1931. The Firmin-Didot volume is a reissue, with a new introduction, or an edition first brought out by that firm in I 846 .

Holdings: $\mathrm{A}$ and $\mathrm{C}$ have another edition (Paris, Garnier, I894). B has (Paris, Charpentier, 1839).

Comment: Madame de Staël (I766-I8I7) rendered her greatest service in introducing German literature and philosophy to the 
French, and her work is of interest to students of both French and German. The Shaw list calls for a complete set of her works in 17 volumes ( $1820-21$ ).

It is difficult to attach exclusive importance to the date and edition cited here. Others of later date were available and in print when the Mohrhardt list was made. Hence, this date cannot be regarded as of great significance.

\section{Results of Case Studies}

The distinction between the specific imprint date of a given volume or edition and the timelessness of certain authors and their works, has often been emphasized in this study. This distinction is emphasized by the cases which have been examined, and at the same time observation of this distinction is necessary to thorough analysis of the cases themselves.

Six of the oldest items in the Shaw list may be said to fall into a group of literary works in a twilight zone of interest, viz., Barlow, Bartram, Musgrave's translation of Camoes, Dennie, Fuller, and Sedgwick. Johnson's Rambler may be included in this group also, although Johnson is clearly of much greater interest today than the six others. It is easy to believe that had the Rambler not already been printed so many times, a modern edition might be available. Of the six, the dates of Fuller and Sedgwick are open to question within the space of a few decades (likewise the Rambler), but whatever the edition chosen, they would still be relatively old. The set of LeSage falls into a similar category.

The case of Fontenelle is similar but the possibility of variation between the imprint dates of $I 82 I$ and I9I I is much wider.

In their respective fields of "History" and "Philosophy," the works of Long and Hutcheson are likewise of minor interest.

The case of Roper's Life is clearly open to question. Selection of an edition with so early a date may have been an oversight. Within a few years of publication of the Shaw list, however, the edition specified was clearly superseded by a new one.

All three of the oldest items in the Mohrhardt list are puzzling in bibliographical detail. They are cited with their earliest dates of issue, but the books to be bought from the publishers are obviously new impressions. That no substantial changes have been made since they were first published is equally evident. All three, especially Smith's Dictionary, are staples by authors of more widely known works. They are in fields and on subjects in which the occasion and demand for revision or new works are relatively slight. The English-Latin Dictionary is, as Fuller has said (Case 6), one of the "auxiliary books, only to be repaired to on occasions," but when those occasions arise it must be at hand.

\section{Holdings of the Libraries Surveyed}

The fifteen titles were not generally found in five college libraries surveyed. Library B was first, with two titles as specified and variant editions of five titles. Library A held two titles as specified and four in other editions. Library $\mathrm{C}$ held two titles in different editions. Library $\mathrm{E}$ held one specified and one variant title. Library $\mathrm{D}$ held none.

Six of the titles were not found in any of the libraries. They are among the rarer ones and are not always found in some of the largest research libraries. Two titles were found once but in different editions. Two were found in two libraries each but in different editions. Two were found to be held by three libraries (a total of six copies) but in different editions. Two titles were found in one library each, in the specified editions. One title was held by three libraries. 
Theoretically, the three four-year colleges ( $A, B$, and $C$ ) might have had all of the specified titles in the Shaw list or 36 holdings in all. Actually there were 2, or 5.6 per cent, plus 6 , or I 6.7 per cent, in different editions. Thus, in a total of $\mathbf{2 2 . 2}$ per cent of the possible holdings, the title specified or a reasonable substitute was available. These colleges made a better showing in the Mohrhardt titles, having two out of a possible nine or $\mathbf{2 2 . 2}$ per cent as specified, and 5, or 55.5 per cent, in different editions.

One of the junior colleges had none in either list, while the other had one title in the Mohrhardt list and one from the Shaw list in a different edition.

That more of the titles were not found in the libraries surveyed is itself testimony that they are not indispensable. None of the largest research libraries in New York City had them all.

\section{Indications of Obsolescence}

The first sign of obsolescence as recorded in the studies previously referred to was the extremely short life of many books (as indicated by the low mean ages); the second is, paradoxically, apparent longevity. Books in the first group die quickly and are forgotten. Books in the second live long because there is not enough interest in them to revise them and bring them upto-date or because there is not enough interest in the field to displace them.

This may serve as a partial explanation of the low rate of obsolescence in the "Classics," where developments have been slow and interest has been waning.

It is fundamental that for a college library books may become obsolete while their authors may not. Repeated new editions are a sign that books may become obsolete while an author and the essence of his works may not. Early editions of Shakespeare are not suitable for the use of the undergraduate student. $\mathrm{He}$ is expected to have a modern edition with revisions in text and orthography and with glossaries and notes.

Conversely, though an obsolete book does not make a forgotten author, a forgotten author does make an obsolete title. Some of the oldest titles in the Shaw list fall in the twilight zone of oblivion. Such a case was that of Dennie, whose Lay Preacher essays existed only in two meager selections. As has been indicated (Case 4), his failure to get more published has doomed him to obscurity. He was not entirely forgotten, however, as evidenced by the reprint issued in 1943. If this reprint is substituted, this author and title jump from an imprint date of 1796 to 1943 or a matter of 147 years. This later date is testimony to greater interest than the earlier date; it confirms what the purchasing agent said about the relation of supply and demand in out-of-print books.

That the Shakespeare titles were al! more recently published than the fifteen titles studied in detail is not an indication that the fifteen have shown greater resistance to obsolescence, but quite the reverse. And this leads to the proposition that, barring extraordinary commercial vicissitudes, out-of-print volumes are relatively obsolete for the purposes of the college library. With few exceptions, if they are not soon revived in newer editions or reprints, they will pass away altogether. Being out-ofprint reflects to a degree lack of sales and, consequently, lack of interest. And being out-of-print is itself a physical barrier to full expression of interest. Revival of a title in a reprint or new edition, beyond removing this barrier, will not per se do much to keep a dying work alive. Rather the revival must be the result of renewed or continued interest in the author himself and in the lasting appeal of the content of his work. 